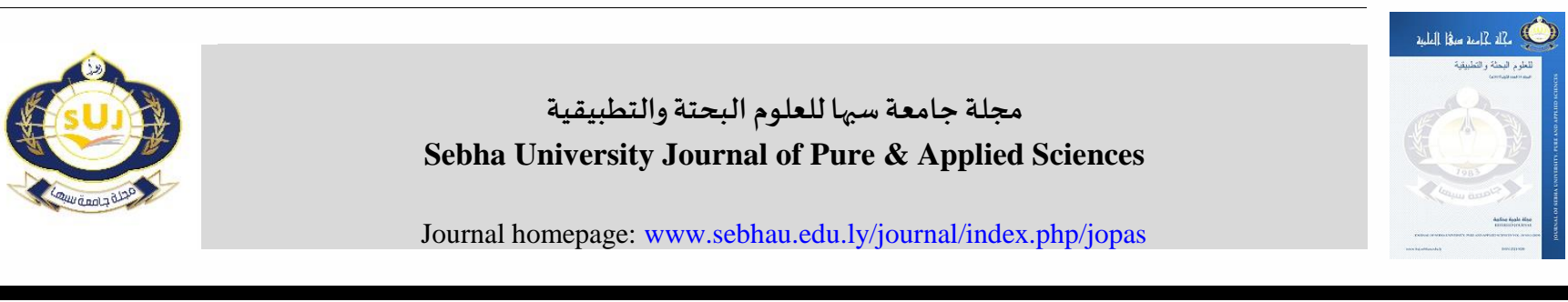

\title{
Theoretical and Spectroscopic Studies of SN Donor Thiosemicarbazone Ligand and Its Pt(II) Complex
}

*Amna Qasem Ali, Boubaker Hosouna, Khadija Abdusslam Ahmida and Abdulasalam Amhamed Mohamed Alshreef

Chemistry department, Faculty of Science, Sebha University, Libya

\section{Keywords}

Bidentate

binding energy

docking results

thiosemicarbazone

Pt(II) complex

\begin{abstract}
A B S T R A C T
Sulphur-nitrogen(SN) donor thiosemicarbazone ligand [(Z)-N-ethyl-2-(5-methyl-2-oxoindolin-3ylidene)hydrazinecarbothioamide] and its $\mathrm{Pt}(\mathrm{II})$ complex were synthesized by condensation method. The compounds were structurally characterized by elemental analysis CHNS, FT-IR, and NMR analysis. The elemental analyses data for the compounds were in good agreement with the theoretical values. The melting point of the complex was higher than the ligand, as expected. The FT-IR spectral data reflect a bidentate bonding of thiosemicarbazone ligand to $\mathrm{Pt}(\mathrm{II})$ ion through thioketo sulfur and azomethine nitrogen. The docking results (theoretical results) of these compounds show that the binding energy between DNA and Pt(II) complex was found to be less than that of the Schiff base ligand (L) in the sense that it has higher stability at various stages and angles. The strength of docking between DNA and Pt(II) complex was also found to be that stronger than the Schiff base ligand (L).
\end{abstract}

$$
\begin{aligned}
& \text { دراسـة طيفية وحسـابية لمرتبط ثN ثايوسيميكاربازون المعطي ومعقده مع البلاتين (II) } \\
& \text { امنة قاسم علي و بوبكر مفتاح حسونة و خديجة عبد السلام احميدة و عبدالسلام امحمد محمد الشريف } \\
& \text { قسم الكيمياء، كلية العلوم، جامعة سبها، ليبيا }
\end{aligned}
$$

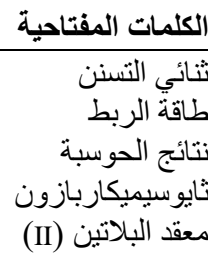

(Z) -N-ethyl-2-(5-methyl-2-oxoindolin-] تم تحضير مرتبط ثيوسيميكاربازون المعطي بالكبريت والنيتروجين

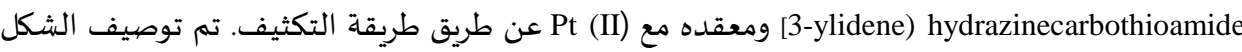
البنائي للمركبات عن طريق تحليل العناصر CHNS و FT-IR وتحليل الرنين المفناطيسي النووي. كانت نتائج

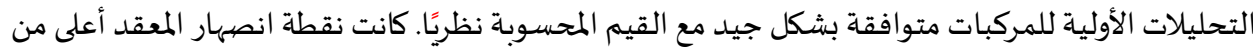
نقطة انصهار المرتبط ، كما هو متوقع. عكست التحالبل الطيفية FT-IR ارتباطًا ثنائيًا بين مرتبط ثيوسيميكاربزون مع أيون من من خلال ثيوكيتو الكبريت و نيتروجين الأزوميثين .أظهرت النتائج الحسابية

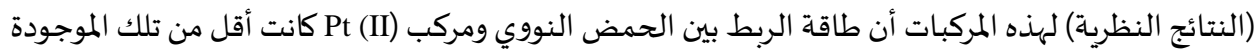
في المرتبط (قاعدة شيف) (L) بمعنى أن لديها ثباتًا أعلى في مراحل مختلفة وكذلك في الزوايا. تم الحصيول على قوة

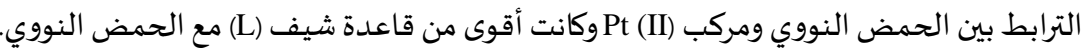

\section{Introduction}

\subsection{Thiosemicarbazones}

Thiosemicarbazones are an attractive class of compounds for their pronounced biological activities. They are actively associated with antibacterial, antifungal herbicidal, and anticancer activities (1-3). Thiosemicarbazones compounds are generally prepared by condensation of an aldehyde or a ketone with a thiosemicarbazide even in the absence of any catalyst either at room temperature or by heating for a few hours (4). Thiosemicarbazones have been intensively studied because of their inhibitory action on the DNA enzyme ribonucleotide diphosphate reductase, as well as their selectivity toward hormone-responsive cancers (5). The thiosemicarbazone ligand usually coordinates with a metal ion through the imine nitrogen and the sulfur atom [6]. The synthesis and the quantum chemical calculations of 5-methoxyisatin-3-(Ncyclohexyl), its Zn (II) \& Ni (II) complexes (7), and 5-methoxyisatin3-(N-cyclohexyl)thiosemicarbazone (8) were studied. The

*Corresponding author:

E-mail addresses: Amn.Abdalhafid@sebhau.edu.ly, (B. Hosouna) Bou.Hosouna@ sebhau.edu.ly, (K. A. Ahmida) Kha.Ahmed@ sebhau.edu.ly, (A. A. M. Alshreef) abdu.alshreef@ sebhau.edu.ly Article History : Received 25 January 2021 - Received in revised form 25 March 2021 - Accepted 15 April 2021 
thiosemicarbazones likely possess anti-HIV activity according to 3D pharmacophoric distance map analysis (9). Quantum chemical calculations and IR studies on Zn (II) and Ni (II) complexes of 5fluoro-isatin -3-( $N$-benzylthiosemicarbazone) have recently been reported (10). Thiosemicarbazones are efficient on specific biological mechanisms because of their chelating ability towards trace metal ions such as Pt(II) ions. Platinum(II) complexes with thiosemicarbazones are particularly attractive because of their antitumor, antibacterial, antiviral, and cytotoxic activities [11]. Platinum compounds have been tested in some clinical trials in molecularly unselected prostate cancer patients [12-13].

\subsection{Molecular docking}

AutoDock 4.2 predicts the bound conformations of a small, flexible ligand to a non-flexible macromolecular target of known structure. The technique combines simulated annealing for conformation searching with a rapid grid-based method of energy evaluation based on the AMBER force field. AutoDock has been optimized in performance without sacrificing accuracy; it incorporates many enhancements and additions, including an intuitive interface (14). The interaction of a drug with its receptor is a complex problem. Many forces are involved in the intermolecular association: hydrophobic, dispersion, or van der Waals, hydrogen bonding, and electrostatic bonding. The major force for binding appears to be hydrophobic interactions, but the specificity of the binding appears to be controlled by hydrogen bonding and electrostatic interactions. The process of docking a compound to a binding site tries to mimic the natural course of interaction of the compound and its receptor via a lowest energy pathway (15). In this study we will show the synthesis and characterization of SN donor thiosemicarbazone ligand (Z)-N-ethyl-2-(5-methyl-2-oxoindolin-3-ylidene)

hydrazinecarbothioamide and its $\mathrm{Pt}(\mathrm{II})$ complex, demonstrate the application of computational methods for the estimate of the binding energy between DNA and these compounds and the most stable compound between them.

\section{Experimental}

\subsection{Materials and methods}

Schiff base ligand and $\mathrm{Pt}(\mathrm{II})$ complex were prepared and reported previously (16-17). All chemicals were purchased from Aldrich Chemicals. Commercial-grade solvents and reagents were used as supplied without further purification. Elemental analysis was carried out using a PerkinElmer 2400 series-11 CHN/O analyzer (Waltham, MA, USA). Infrared, electronic, and nuclear magnetic resonance spectra were recorded on PerkinElmer 2000, Perkin Elmer-Lambda 25 , and Bruker $500 \mathrm{MHz}$ spectrometer at room temperature using DMSO-d 6 as solvent and TMS as an internal standard.

2.2. Synthesis of Schiff base ligand and its $\mathrm{Pt}(\mathrm{II})$ complex 2.2.1. Synthesis of (Z)-N-Ethyl-2-(5-methyl-2-oxoindolin-3ylidene)hydrazinecarboth- ioamide.

The Schiff base ligand was synthesized by refluxing the reaction mixture of hot ethanolic solutions $(30 \mathrm{ml}$ each) of 4-ethyl-3thiosemicarbazide $(0.01 \mathrm{~mol})$ and 5-methylisatin $(0.01 \mathrm{~mol})$ for $2 \mathrm{~h}$ (Scheme 1). The precipitates formed during reflux were filtered and washed with cold ethanol and finally stored in a vacuum desiccator over $\mathrm{P}_{2} \mathrm{O}_{5}$. The yellow crystals were grown acetonedimethylformamide $(3: 1)$ by slow evaporation at room temperature.

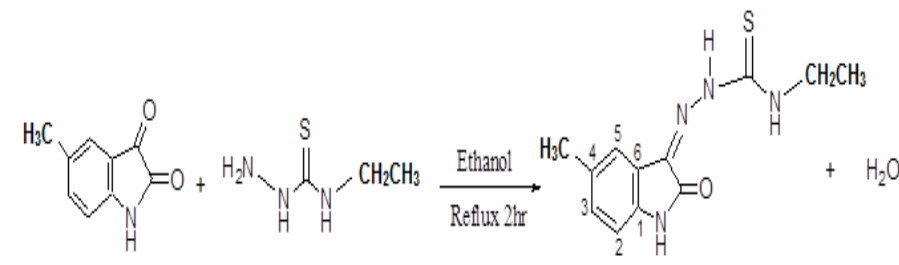

Scheme 1: The synthesis route of the Schiff base ligand.

$\mathbf{C}_{12} \mathrm{H}_{14} \mathbf{N}_{4} \mathrm{OS}$ : Yellow crystals; MP: $260.0{ }^{\circ} \mathrm{C}$ to $261.8{ }^{\circ} \mathrm{C}$; yield: 80\%; analytical calculated values : C (54.94\%), H (5.38\%) and $\mathrm{N}$ (21.36\%); analytical results (experimental): C (54.83\%), H (5.41\%) and $\mathrm{N}(21.46 \%)$; selected IR data $\left(\mathrm{KBr}\right.$ pellet, $\left.v_{\max } / \mathrm{cm}^{-1}\right): 3343$ to $3190(\mathrm{NH}), 1691(\mathrm{C}=\mathrm{O}), 1629(\mathrm{C}=\mathrm{N}), 1545(\mathrm{C}=\mathrm{C})$ and 1206/794 $(\mathrm{C}=\mathrm{S}) ;{ }^{1} \mathrm{H}$ NMR $\left(500 \mathrm{MHz}, \mathrm{DMSO}-\mathrm{d}_{6}\right)[\delta(\mathrm{ppm})]: 12.53(\mathrm{~s}, 1 \mathrm{H}$, thiosemicarbazide N-NH), 11.09 (s, 1H, indole N-H ), 9.28 to 9.25 (t, $1 \mathrm{H}, \mathrm{CS}-\mathrm{NH}, \mathrm{J}=5.8 \mathrm{~Hz}), 7.50(\mathrm{~s}, 1 \mathrm{H}$, indole $\mathrm{C} 5-\mathrm{H}), 7.17(\mathrm{~d}, 1 \mathrm{H}$, indole $\mathrm{C} 2-\mathrm{H}, \mathrm{J}=7.9 \mathrm{~Hz}), 6.83(\mathrm{~d}, 1 \mathrm{H}$, indole $\mathrm{C} 3-\mathrm{H}, \mathrm{J}=7.9 \mathrm{~Hz})$, 3.68 to 3.62 to (p, $2 \mathrm{H}$, thiosemicarbazide $\left.\mathrm{CH}_{2}, \mathrm{~J}=6.8 \mathrm{~Hz}\right), 2.31$ (s, $3 \mathrm{H}$, indole $\left.\mathrm{CH}_{3}\right), 1.21$ to 1.19 (t, $3 \mathrm{H}$, thiosemicarbazide $\mathrm{CH}_{3}, \mathrm{~J}=7$ ); ${ }^{13} \mathrm{C}$ NMR (125 MHz, DMSO-d6) [ $\delta$ (ppm)]: 176.70, 162.66, 139.99, 131.70, 131.52, 131.29, 121.14, 119.98, 110.78, 40.11, 20.56, 14.00.

2.2.2. Synthesis of bis $\{N$-ethyl- $N$-[5-methyl-2-(oxo- $\kappa O)-1,2$ dihydro-3H-indol-3- ylidene]carbamohydrazonothioato- $\kappa^{2} N$, $S\}$ platinum(II) $\left\{\mathrm{Pt}(\mathrm{L})_{2}\right\}$.

The Schiff base platinum(II) complex $\mathrm{Pt}(\mathrm{L})_{2}$ was synthesized by adding with the constant stirring equivalent amount of the Schiff base ligand dissolved in absolute $\mathrm{EtOH}(30 \mathrm{ml})$ to the potassium tetrachloroplatinate(II) $\left(\mathrm{K}_{2} \mathrm{PtCl}_{4}\right)$ dissolved in $30 \mathrm{ml}$ EtOH. The reaction mixture was reflux for $2 \mathrm{~h}$ (Scheme 2). The precipitates formed during reflux were filtered and washed with cold ethanol and finally stored in a vacuum desiccator over $\mathrm{P}_{2} \mathrm{O}_{5}$.

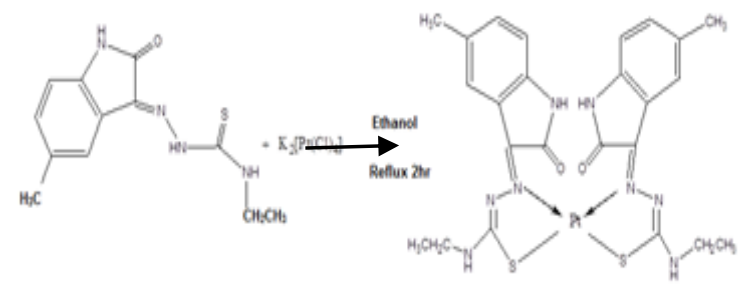

Scheme 2: The synthesis route of the platinum complex.

$\mathbf{C}_{24} \mathbf{H}_{26} \mathbf{N}_{8} \mathbf{O}_{2} \mathbf{P t S} \mathbf{S}_{2} \quad\left\{\mathrm{Pt}(\mathrm{L})_{2}\right\}$ : Brown; MP: $>300{ }^{\circ} \mathrm{C}$; yield: $75 \%$; analytical calculated values C (40.16\%); H (3.65\%); N (15.61\%); Pt (27.78\%); analytical results (experimental): C (40.21\%); H (3.46\%); $\mathrm{N}(15.39 \%)$; Pt $(27.57 \%)$; selected IR data $\left(\mathrm{KBr}\right.$ pellet, $\left.v_{\max } / \mathrm{cm}^{-1}\right)$ : 3223 to $3180(\mathrm{NH}), 1693(\mathrm{C}=\mathrm{O}), 1618(\mathrm{C}=\mathrm{N}), 788(\mathrm{C}-\mathrm{S}) ;{ }^{1} \mathrm{H}$ NMR $\left(500 \mathrm{MHz}, \mathrm{DMSO}-\mathrm{d}_{6}\right)(\delta(\mathrm{ppm})): 11.11(\mathrm{~s}, 1 \mathrm{H}$, indole $\mathrm{N}-\mathrm{H}), 9.29$ to $9.27(\mathrm{t}, 1 \mathrm{H}, \mathrm{CS}-\mathrm{NH}, \mathrm{J}=5.6 \mathrm{~Hz}), 7.50(\mathrm{~s}, 1 \mathrm{H}$, indole $\mathrm{C} 5-\mathrm{H}), 7.18$ to $7.16(\mathrm{dd}, 1 \mathrm{H}$, indole $\mathrm{C} 2-\mathrm{H}, \mathrm{J}=7.9 \mathrm{~Hz}), 6.83$ to $6.76(\mathrm{dd}, 1 \mathrm{H}$, indole $\mathrm{C} 3-\mathrm{H}, \mathrm{J}=7.9 \mathrm{~Hz}$ ), 3.66 to 3.61 to (p, $2 \mathrm{H}$, thiosemicarbazide $\mathrm{CH}_{2}$, J $=6.6 \mathrm{~Hz}), 2.30\left(\mathrm{~s}, 3 \mathrm{H}\right.$, indole $\left.\mathrm{CH}_{3}\right), 1.24$ to $1.20(\mathrm{t}, 3 \mathrm{H}$, thiosemicarbazide $\mathrm{CH}_{3}, \mathrm{~J}=7.1$ ) and $\mathrm{UV}$-Vis [DMSO $\lambda_{\max }, \mathrm{nm}$ ]: 266 , 389,455 .

\subsection{Molecular docking in Vacuo}

After all the individual structures were completely optimized, the methyl red molecules were docked into the CD's. Hydrogen atoms were added using the merged non-polar hydrogen keyword in Auto dock 4.2 software. The Kollman and Gasteiger charges were assigned on the macromolecule while the charges on ligand were be added automatically. For the autogrid calculation, the grid map of $40 \mathrm{x} 40 \mathrm{x}$ $40 \mathrm{~A} 3$ was used for CD's molecules. Gridpoint spacing of $0.375 \mathrm{~A}$ was used and centred on the macromolecule. A total of 21 rigid docking tests in vacuo were constructed using Autodock 4.2 software and a total of 100 runs were performed. The results of cluster ranked in the order of increasing energy with 2.0 A tolerence. In the Lamarkian Genetic Algorithm parameters, 150 individuals of population size, $2.5 \times 106$ maximum number of energy evaluation, $2.7 \times 104$ maximum number of generations, elitism value 1 which is the number of top individuals to survive to next-generation, 0.02 rate of gene mutation, crossover rate of 0.8 were used. The pseudo-Solid and West search method having the maximum 300 iterations of local search with 0.06 probability of performing a local search on the individual were adopted. Then the maximum number of consecutive successes and failure before doubling or having the local search step size was 4 in both cases. The lower bound on rho $(\rho)$, the termination criterion for the local search was set on 0.01 . The configurations obtained were ranked in clusters which list from the lowest to the high set binding energy.

\section{Results and discussion}




\subsection{Spectral characterization}

\subsubsection{IR studies}

IR spectrum of Schiff base ligand (figure 1) showed absorption bands in the 3343-3169 and $1702-1691 \mathrm{~cm}^{-1}$ regions resulting from the $\mathrm{NH}$ and $\mathrm{C}=\mathrm{O}$ functions, respectively (18-19). The various absorption bands in the region $1667-1593,1586-1450 \mathrm{~cm}^{-1}$ may be assigned due to $(\mathrm{C}=\mathrm{N}),(\mathrm{C}=\mathrm{C})$ respectively $(20)$. Characteristic strong bands at $1212-1042 \mathrm{~cm}^{-1}$ are assigned to $v(\mathrm{C}=\mathrm{S})(21)$.

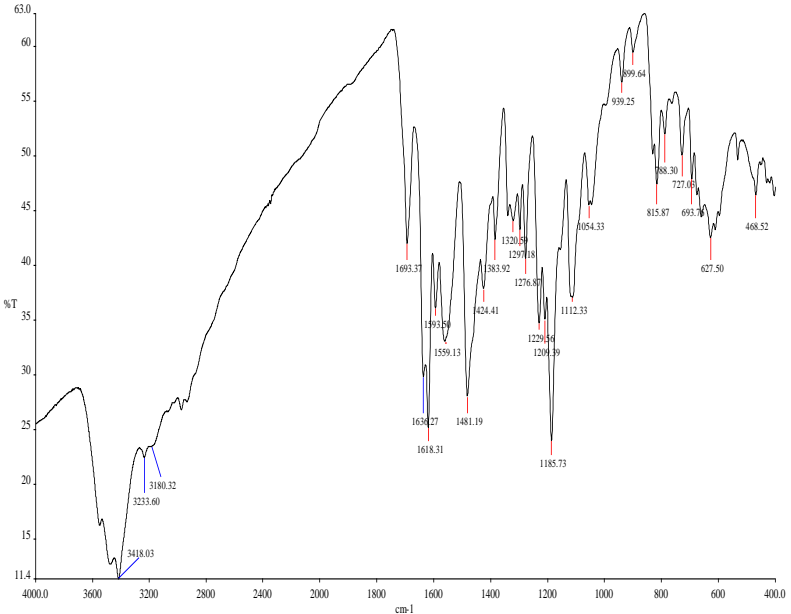

Figure 1: FT-IR spectrum of (Z)-N-Ethyl-2-(5-methyl-2oxoindolin-3-ylidene)hydra- zinecarbothioamide $(\mathbf{L})$ in $\mathrm{KBr}$.

In comparison with the spectrum of the Schiff base, the Pt (II) complex (figure 2) shows the carbonyl oxygen band as a strong band at $1693 \mathrm{~cm}^{-1}$ which suggests that the $(\mathrm{C}=\mathrm{O})$ group does not take part in bonding. The band of $v(\mathrm{C}=\mathrm{N})$ in the region $1613-1625 \mathrm{~cm}^{-1}$ in the metal complex, showing the shift of the band to lower wavenumbers and indicating that the nitrogen atom of the azomethine group is coordinated to the metal ion. This is further supported by the band around $741-788 \mathrm{~cm}^{-1}$ in the metal complex due to $v(\mathrm{C}-\mathrm{S})(22)$. Thus the IR spectral results of platinum(II) complex provide strong evidence for the complexation of Schiff base with the platinum ion in a bidentate manner.

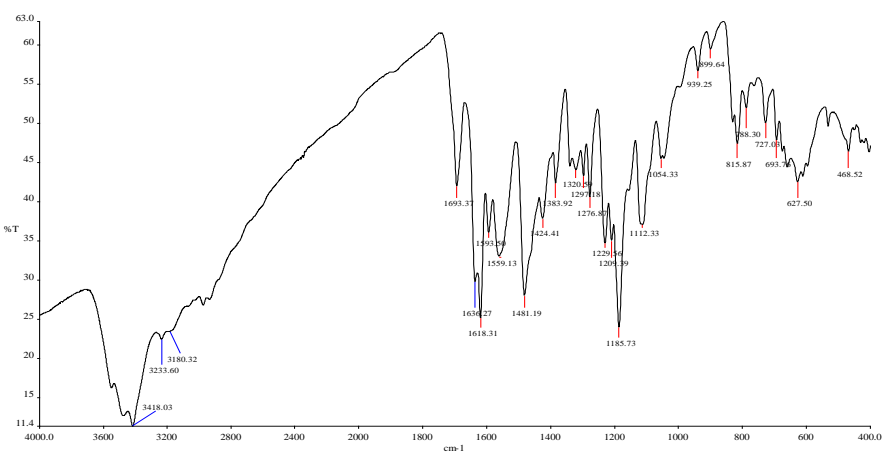

Figure 2: FT-IR spectrum of bis $\{N$-ethyl- $N$-[5-methyl-2-(oxo$\kappa O)$-1, 2-dihydro- $3 H$-indol-3-ylidene]carbamohydrazonothioato$\left.\kappa^{2} N^{\prime}, S\right\}$ platinum(II) $\left\{\mathbf{P t}(\mathbf{L})_{2}\right\}$ in $\mathrm{KBr}$.

\subsection{2. ${ }^{1} \mathrm{H}$ NMR studies}

The ${ }^{1} \mathrm{H}$ NMR spectrum of the Schiff base ligand (figure 3) exhibited two separate singlets at $\delta(12.5), \delta(11.0)$ attributed to $\mathrm{N}$ $\mathrm{NH}$ of thiosemicarbazide and indole N-H moiety, respectively and one separate triplet at $\delta(9.3)$ attributed to CS-NH proton of the thiosemicarbazide moiety as reported previously for similar compounds (23).

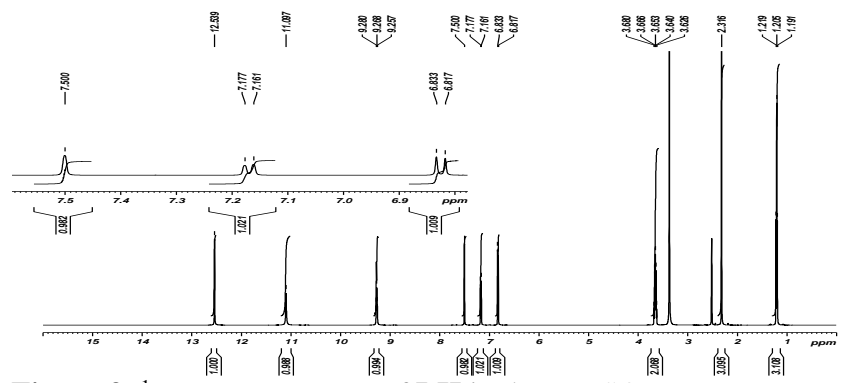

Figure 3: ${ }^{1} \mathrm{H}$ NMR spectrum of $\mathbf{L H}$ in $\mathrm{d} 6$ - DMSO.

The ${ }^{1} \mathrm{H}$ NMR ( $\mathrm{d}_{6}$-DMSO) spectrum of $\mathrm{Pt}(\mathrm{II})$ complex (figure 4) show approximately the same peaks identical to those of the free ligand, except that the peak due to the NH group resonance is absent. This finding is considered as additional evidence of the deprotonation of $\mathrm{NH}$ during metal complexation as reported previously for similar compounds (24).

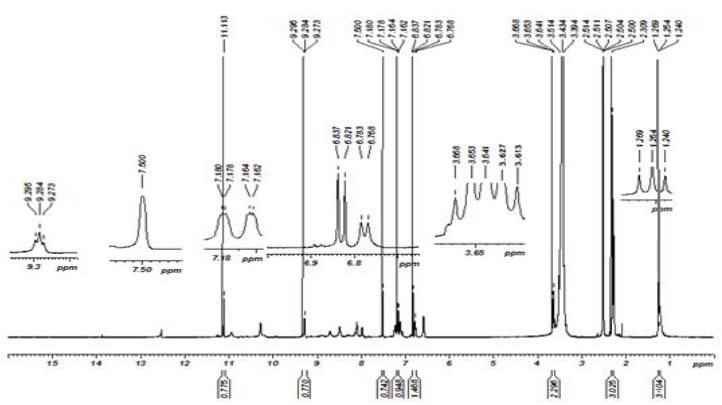

Figure 4: ${ }^{1} \mathrm{H}$ NMR spectrum of $\left[\operatorname{Pt}(\mathbf{L})_{2}\right]$ in $\mathrm{d}_{6}$ - DMSO.

\subsubsection{UV-Vis study}

The UV-Vis absorption spectrum (figure 5) of the Pt(II) complex was measured within the UV-Vis region (200-800 nm) using

Capped sticks design 1 Capped sticks design Space fill design

DMSO. Two absorption bands with varied intensity can be observed. The band observed at $389 \mathrm{~nm}$ are attributable to metal-to ligand charge transfer transitions, whereas the band observed at a lower frequency at $455 \mathrm{~nm}$ correspond to $\mathrm{d}-\mathrm{d}$ transitions, which suggest a square-planar geometry [25].

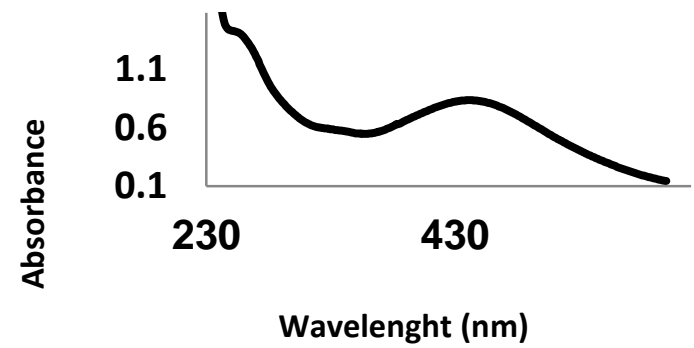

Figure 5: UV-Vis spectrum of $\left\{\mathbf{P t}(\mathbf{L})_{2}\right\}$ in DMSO.

\subsection{Theoretical results (Docking):}

This part of the study will show the docking software results. Firstly, the binding energies $(\mathrm{kcal} / \mathrm{mol})$ were calculated using docking (Autodock 4.2) for DNA with water in vacuum were given in table 1 . The structures of the lowest energy conformation from Autodock at run 100, for (Water-DNA) inclusion complex, were given in figure 6.

Table 1: The binding energies $(\mathrm{kcal} / \mathrm{mol})$ calculated using docking (Autodock 4.2) for DNA with water in a vacuum.

Water 


\begin{tabular}{|c|c|c|}
\hline Host & Energy & $\begin{array}{c}\text { Ligand (water) } \\
\text { Kcal/mol }\end{array}$ \\
\hline \multirow{2}{*}{ DNA } & E $_{\text {binding }}$ & -2.09 \\
& E lectrostatic & -0.29 \\
& E $_{\text {nonbonded }}$ & -1.80 \\
& E $_{\text {torsional }}$ & +0.00 \\
& E Final Intermolecular & -2.09 \\
& EFinal Total Internal & +0.00 \\
\hline
\end{tabular}

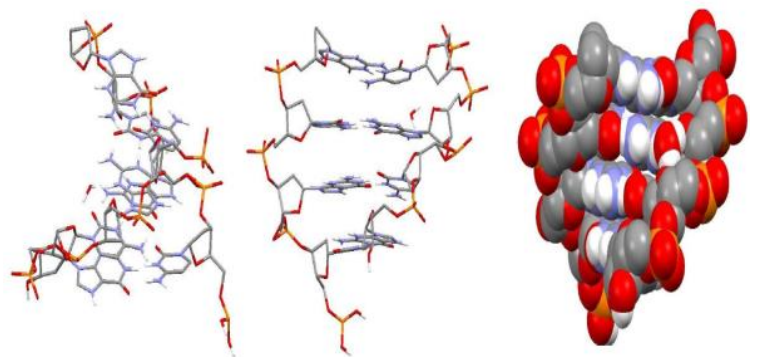

Figure 6.: The structures of the lowest energy conformation from Autodock at run 100, for (Water-DNA) inclusion complex.

Secondly, the binding energies $(\mathrm{kcal} / \mathrm{mol})$ were calculated using docking (Autodock 4.2) for DNA with Schiff base ligand (L) as well as for DNA with Pt(II) complex in vacuum were given in tables 2 and 3 respectively. The structures of the lowest energy conformation from Autodock at running 100, for the (Schiff base ligand-DNA) inclusion complex as well as for the (Pt(II) complex-DNA) inclusion complex were given in figures 7 and 8 respectively.

Table 2: The binding energies $(\mathrm{kcal} / \mathrm{mol})$ calculated using docking (Autodock 4.2) for DNA with Schiff base ligand (L) in a vacuum.

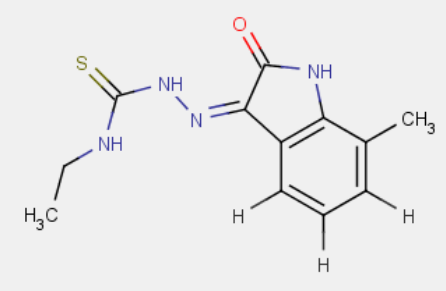

\begin{tabular}{|c|c|c|}
\hline Host & Energy & $\begin{array}{c}\text { Schiff base ligand } \\
\text { Kcal/mol }\end{array}$ \\
\hline \multirow{4}{*}{ DNA } & E binding $_{7}$ & \\
& Electrostatic $_{7}$ & -5.09 \\
& E $_{\text {nonbonded }}$ & -0.11 \\
& E $_{\text {torsional }}$ & -6.47 \\
& EFinal Intermolecular & +1.49 \\
& EFinal Total Internal & -6.58 \\
\hline
\end{tabular}

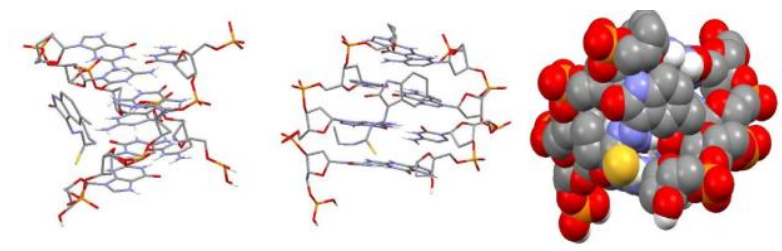

Capped sticks design 1 Capped sticks design 2 Space fill design

Figure 7: The structures of the lowest energy conformation from Autodock at running 100, for (Schiff base ligand-DNA) inclusion complex.

Table 3: The binding energies ( $\mathrm{kcal} / \mathrm{mol}$ ) calculated using docking (Autodock 4.2) for DNA with Pt(II) complex in a vacuum.

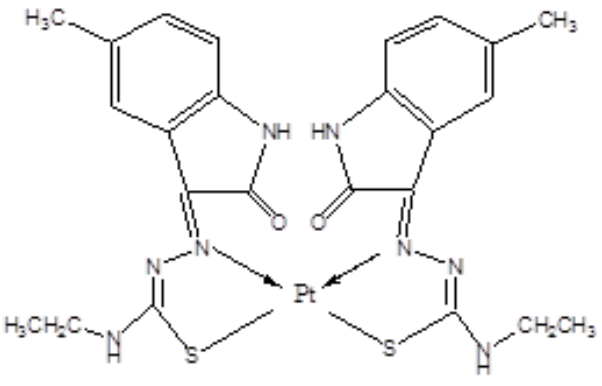

\begin{tabular}{|c|c|c|}
\hline Host & Energy & $\begin{array}{l}\text { Pt(II) complex } \\
\text { Kcal/mol }\end{array}$ \\
\hline DNA & $\begin{array}{l}\text { Ebinding } \\
\text { Electrostatic } \\
\text { Enonbonded }_{\text {non }} \\
\text { Etorsional } \\
\text { EFinal Intermolecular } \\
\text { EFinal Total Internal }^{\text {E }}\end{array}$ & $\begin{array}{l}-5.57 \\
-0.06 \\
-7.15 \\
+1.65 \\
-7.21 \\
-0.91\end{array}$ \\
\hline
\end{tabular}

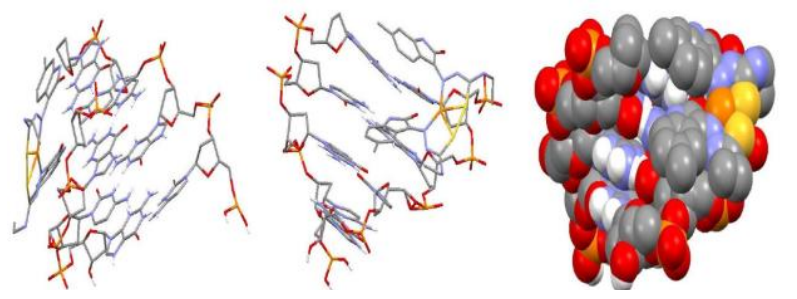

Capped sticks design 1 Capped sticks design 2 Space fill design

Figure 8: The structures of the lowest energy conformation from Autodock at run 100, for (Pt(II) complex-DNA) inclusion complex.

The results showed the binding energy between DNA and the Schiff base Pt(II) complex was found to be less than that of the Schiff base ligand (L) in the sense that it has higher stability at various stages and angles. The strength of docking between DNA and Schiff base Pt(II) complex was also found to be that stronger than the Schiff base ligand (L).

\section{Conclusion}

(Z)-N-ethyl-2-(5-methyl-2-oxoindolin-3-

ylidene)hydrazinecarbothioamide and its $\mathrm{Pt}(\mathrm{II})$ complex were synthesized and characterized by several techniques. The compounds were studied theoretically (Docking). The ligand act as a bidentate ligand towards Pt(II) ion. The simulation of the interaction between methyl red and DNA differs from that of the compounds under study, in terms of power and less docking energy. The binding energy between DNA and Pt(II) complex $(-5.57 \mathrm{Kcal} / \mathrm{mol})$, was found to be less than that of the Schiff base ligand $(\mathrm{L})(-5.09 \mathrm{Kcal} / \mathrm{mol})$, in the sense that it has higher stability at various stages and angles. The strength of docking between DNA and Pt(II) complex was also found to be that stronger than the Schiff base ligand (L).

\section{Acknowledgment}

The financial support for this study was provided by the Ministry of Higher Education and the University of Sebha (Libya) for a scholarship.

\section{References}

[1]- Pahontu E, Julea F, Rosu T, Purcarea V, Chumakov Y, Petrenco $\mathrm{P}$, Gulea A. Antibacterial, antifungal and in vitro antileukaemia activity of metal complexes with thiosemicarbazones. Journal of cellular and molecular medicine. 2015 Apr;19(4):865-878. https://doi.org/10.1111/jcmm. 12508

[2]- More M.S, Joshi P.G, Mishra Y.K, Khanna P.K. Metal complexes driven from Schiff bases and semicarbazones for biomedical and allied applications: a review. Materials Today Chemistry. $\quad 2019 \quad$ Dec $1 ; \mathbf{1 4}: 100195$. https://doi.org/10.1016/j.mtchem.2019.100195 
[3]- Hassan M, Ghaffari R, Sardari S, Farahani Y.F, Mohebbi S. Discovery of novel isatin-based thiosemicarbazones: synthesis, antibacterial, antifungal, and antimycobacterial screening. Research in Pharmaceutical Sciences. 2020 Jun;15(3):281. https://dx.doi.org/10.4103\%2F1735-5362.288435

[4]- Singh G.S, Desta Z.Y. Isatins as privileged molecules in design and synthesis of spiro-fused cyclic frameworks. Chemical Reviews. 2012 Nov 14;112(11):6104-6155. DOI: $10.1021 / \mathrm{cr} 300135 \mathrm{y}$

[5]- Tardito S, Marchio L. Copper compounds in anticancer strategies. Current medicinal chemistry. 2009 Apr $1 ; \mathbf{1 6}(11): 1325-1348$. https://doi.org/10.2174/092986709787846532

[6]- Şen, B., Kalhan, H. K., Demir, V., Güler, E. E., Kayalı, H. A., \& Subaş1, E. (2019). Crystal structures, spectroscopic properties of new cobalt (II), nickel (II), zinc (II) and palladium (II) complexes derived from 2-acetyl-5-chloro thiophene thiosemicarbazone: anticancer evaluation. Materials Science and Engineering: C,98,550-559. https://doi.org/10.1016/j.msec.2018.12.080

[7]- Kandemirli F, Arslan T, Karadayı N, Ebenso EE, Köksoy B. Synthesis and theoretical study of 5-methoxyisatin-3-(Ncyclohexyl)thiosemica- rbazone and its $\mathrm{Ni}$ (II) and $\mathrm{Zn}$ (II) complexes. Journal of Molecular Structure. 2009 Dec 16;938(13):89-96. https://doi.org/10.1016/j.molstruc.2009.09.009

[8]- Kandemirli, F.; Arslan, T.; Koksoy, B. \& Yılmaz, M. Synthesis, Characterization and Theoretical Calculations of 5Methoxyisatin-3-thiosemicarbazone Derivatives. J. Chem. Soc. Pakistan, 2009, Vol. 31, No. , pp. 498-504.

[9]- Bal T.R, Anand B, Yogeeswari P, Sriram D. Synthesis and evaluation of anti-HIV activity of isatin $\beta$-thiosemicarbazone derivatives. Bioorganic \& medicinal chemistry letters. 2005 Oct,15;15(20):4451-4455. https://doi.org/10.1016/j.bmcl.2005.07.046

[10]- Sagdinc S, Köksoy B, Kandemirli F, Bayari SH. Theoretical and spectroscopic studies of 5-fluoro-isatin-3-(Nbenzylthiosemicarbazone) and its zinc (II) complex. Journal of Molecular Structure. 2009 Jan 15;917(2-3):63-70. https://doi.org/10.1016/j.molstruc.2008.06.033

[11]- Hager, S., Ackermann, C. J., Joerger, M., Gillessen, S., \& Omlin, A. Anti-tumour activity of platinum compounds in advanced prostate cancer-a systematic literature review. Annals of Oncology; 2016,27(6), 975-984. https://doi.org/10.1093/annonc/mdw156

[12]- Pasetto, L. M., D’Andrea, M. R., Brandes, A. A., Rossi, E., \& Monfardini, S. The development of platinum compounds and their possible combination. Critical Reviews in $\begin{array}{lll}\text { Oncology/Hematology, 2006, } & 60(1), & 59-75 .\end{array}$ https://doi.org/10.1016/j.critrevonc.2006.02.003

[13]- Muggia, F. Platinum compounds 30 years after the introduction of cisplatin: implications for the treatment of ovarian cancer. Gynecologic oncology, 2009,112(1), 275-281. https://doi.org/10.1016/j.ygyno.2008.09.034

[14]- Morris, G.M., Goodsell, D.S., Huey, R. et al. Distributed automated docking of flexible ligands to proteins: Parallel applications of AutoDock 2.4. J Computer-Aided Mol Des 10, 293-304,(1996). https://doi.org/10.1007/BF00124499

[15]- Fouzia. P., Rumana. Q., Farzana. L. A., S. Kalsoom, and Saima. K. S. A. Investigations of drug-DNA interactions using molecular docking, cyclic voltammetry and UV-Vis spectroscopy. Journal of Molecular Structure 2011,1004,67-73. https://doi.org/10.1016/j.molstruc.2011.07.027
[16]- Amna. Q. A., Siang. G. T., Abdussalam. S., Naser. E. .E., Mohamed B., K. and Amin M. S. A. Synthesis of isatin thiosemicarbazones derivatives: In vitro anti-cancer, DNA binding and cleavage activities. Spectrochimica Acta Part A: Molecular and Biomolecular Spectroscopy, 2014, 125 440-448. https://doi.org/10.1016/j.saa.2014.01.086

[17]- Ali A.Q, Teoh S.G, Salhin A, Eltayeb N.E, Ahamed M.B, Majid A.A. Synthesis of platinum (II) complexes of isatin thiosemicarbazones derivatives: In vitro anti-cancer and deoxyribose nucleic acid binding activities. Inorganica Chimica Acta. $2014 \quad$ May 24;416:235-244 https://doi.org/10.1016/j.ica.2014.03.029.

[18]- Pahontu E, Julea F, Rosu T, Purcarea V, Chumakov Y, Petrenco $\mathrm{P}$, Gulea A. Antibacterial, antifungal and in vitro antileukaemia activity of metal complexes with thiosemicarbazones. Journal of cellular and molecular medicine. 2015 Apr;19(4):865-878. https://doi.org/10.1111/jcmm. 12508

[19]- Balan G, Burduniuc O, Usataia I, Graur V, Chumakov Y, Petrenko P, Gudumac V, Gulea A, Pahontu E. Novel 2formylpyridine 4-allyl-S-methylisothiosemicarbazone and $\mathrm{Zn}$ (II), Cu (II), Ni (II) and Co (III) complexes: Synthesis, characterization, crystal structure, antioxidant, antimicrobial and antiproliferative activity. Applied Organometallic Chemistry. https://doi.org/10.1002/aoc.5423

[20]- Pahonțu E, Paraschivescu C, Ilieș D.C, Poirier D, Oprean C, Păunescu V, Gulea A, Roșu T, Bratu O. Synthesis and Characterization of Novel $\mathrm{Cu}$ (II), Pd (II) and Pt (II) Complexes with 8-Ethyl-2-hydroxytricyclo (7.3.1.02,7)tridecan-13onethiosemicarbazone: Antimicrobial and in Vitro Antiproliferative Activity. Molecules. 2016 May;21(5):674. https://doi.org/10.3390/molecules21050674

[21]- Wiles, D.M., Gingras, B.A., Suprunchuk, T. The C=S stretching vibration in the infrared spectra of some thiosemicarbazones. Canadian Journal of Chemistry. 1967 45, 469-473. doi:10.1139/v67-081. https://doi.org/10.1139/v67081

[22]- Sharma D, Jasinski JP, Smolinski VA, Kaur M, Paul K, Sharma R. Synthesis and structure of complexes (NiII, AgI) of substituted benzaldehyde thiosemicarbazones and antitubercular activity of NiII complex. Inorganica Chimica Acta. $2020 \quad$ Jan $1 ; \mathbf{4 9 9}: 119187$. https://doi.org/10.1016/j.ica.2019.119187

[23]- Ilic SB, Konstantinovic SS, Todorovic ZB, Lazic ML, Veljkovic VB, Jokovic N, Radovanovic BC. Characterization and antimicrobial activity of the bioactive metabolites in streptomycete isolates. Microbiology. 2007 Aug 1;76(4):421428. https://doi.org/10.1134/S0026261707040066

[24]- Matesanz AI, Pérez JM, Navarro P, Moreno JM, Colacio E, Souza P. Synthesis and characterization of novel palladium (II) complexes of bis (thiosemicarbazone). Structure, cytotoxic activity and DNA binding of Pd (II)-benzyl bis (thiosemicarbazonate). Journal of inorganic biochemistry. 1999 Jul 30;76(1):29-37. https://doi.org/10.1016/S01620134(99)00105-1

[25]- Mbugua, S. N., Sibuyi, N., Njenga, L. W., Odhiambo, R. A., Wandiga, S. O., Meyer, M., Lalancette, R. A., \& Onani, M. O. (2020). New Palladium(II) and Platinum(II) Complexes Based on Pyrrole Schiff Bases: Synthesis, Characterization, X-ray Structure, and Anticancer Activity. ACS omega, 5(25), 1494214954. https://doi.org/10.1021/acsomega.0c00360. 